\title{
OS DIREITOS FUNDAMENTAIS DOS ANIMAIS COMO SERES SENCIENTES*
}

\author{
Thaise Santos da Rosa**
}

“Chegará o dia em que todo homem conhecerá o íntimo dos animais. Nesse dia, um crime contra um animal será considerado um crime contra a própria humanidade."

(Leonardo da Vinci)

"Não importa se os animais são incapazes ou não de pensar. O que importa é que são capazes de sofrer." (Jeremy Bentham)

"Não há diferença fundamental entre o Homem e os animais nas suas faculdades mentais (...). Os animais, como o Homem, demonstram sentir prazer, dor, felicidade e sofrimento."

(Charles Darwin)

\section{INTRODUÇÃO}

Em alinhamento com a tendência social de que os animais não humanos são seres sencientes, e por este motivo têm direitos e garantias fundamentais tanto quanto os seres humanos, tende-se a verificar que ambos podem conviver de forma pacífica e

* Trabalho de conclusão de curso apresentado à Faculdade de Direito da Estácio, como requisito parcial à obtenção do título de Bacharel em Direito. Orientador: Prof. Me. Fernando de Alvarenga Barbosa.

** Bacharela em Direito pela Faculdade de Direito da Estácio. 
dividindo os mesmos direitos considerados básicos como o bem estar, à vida, a saúde e a um lar.

Ao longo da história os humanos se dividiam em seus posicionamentos acerca dos animais, nem sempre se pensava nos animais não humanos como membros da família ou seres que sentem dor, frio, fome, amor, por este motivo, grande parte da humanidade explorou e explora os animais não humanos até os dias de hoje.

Entretanto, sempre surgiu pessoas que questionavam este tipo de cultura no mundo inteiro, surgindo uma preocupação com a forma que eram tratados os animais domésticos e não domésticos.

Assim, surgiram os primeiros direitos dos animais ao longo do desenvolvimento mundial. Atualmente várias culturas se dividem quando se trata dos direitos dos animais não humanos, porém a realidade vem modificando a cada dia, com o atual desenvolvimento da humanidade e a preocupação com o futuro das próximas gerações, os humanos tem cada vez mais se preocupado não somente com a natureza, mas com a forma como que se tratam os animais. Em 2012, o IBOPE - Instituto Brasileiro de Opinião Pública e Estatística - publicou que 15,2 milhões de brasileiros se declararam vegetarianos, correspondendo a 8\% da população total do país, e esta realidade é cada vez maior. Mostrando que as novas gerações se preocupam não somente com a sua saúde, mas com o bem-estar da natureza e dos animais. ${ }^{1}$

Mostrando que é possível a convivência pacífica entre os animais não humanos e humanos, podendo os humanos garantir os direitos básicos aos animais não humanos.

\section{O ANIMAL NÃO HUMANO COMO SER SENCIENTE}

De acordo com o dicionário Aurélio ${ }^{2}$, senciente vem do latim sentiens entis que significa capaz de sentir ou perceber

1 IBOPE 2012. Disponível em: <https://vista-se.com.br/ibope-2012-152-milhoes-de-brasileiros-sao-vegetarianos/>. Acesso em: 19 out. 2016.

2 SENCIENTE. In: DICIONÁRIO AURÉLIO. Disponível em: <https://dicionariodoaurelio.com/senciente>. Acesso em: 19 out. 2016. 
através dos sentidos. Em outra forma, seres que possuem ou conseguem receber impressões ou sensações. ${ }^{3}$

Importante salientar que não se deve misturar o conceito de senciente com o de autoconsciência, no qual conceitua-se como a consciência que um sujeito tem de si próprio. ${ }^{4}$

Consoante o Glossário:

Organismos vivos que não apenas apresentam reações orgânicas ou físico-químicas aos processos que afetam o seu corpo (sensibilidade), mas além dessas reações, possuem um acompanhamento no sentido em que essas reações são percebidas como estados mentais positivos ou negativos. Trata-se, portanto, de um indício de que existe um "eu" que vivencia e experimenta as sensações, diferenciando, claramente, "indivíduos vivos" de meras "coisas vivas". ${ }^{5}$

Partindo deste princípio, pode-se definir a senciência como um estado da mente que acompanha as sensações físicas como dor, frio e fome. Pode-se dizer que a senciência corresponde a sensibilidade e consciência, sendo algo que somente será encontrado em seres do reino animal.

Nessa linha de raciocínio, Jeremy Bentham, no século XIX, já discutia acerca do dever da compaixão dos seres humanos perante animais não-humanos, não somente se estes seriam dotados de razão ou linguagem, mas também se poderiam ser capazes de sentir. ${ }^{6}$

3 SENCIENTE. In: DICIONÁRIO ONLINE. Disponível em: <https://www.dicio. com.br/senciente/>. Acesso em: 19 out. 2016.

4 AUTOCONSCIÊNCIA, op. cit.

5 SENTIENS. In: GLOSSÁRIO. Disponível em: <http://www.sentiens.net/top/ PA_GLOSSARIO_top.html>. Acesso em: 19 out. 2016

6 AGÊNNCIA DE NOTÍCIAS DE DIREITO DOS ANIMAIS. Senciência. Disponível em: <http://www.anda.jor.br/10/06/2009/senciencia>. Acesso em: 19 out. 2016 
Outrossim, em discussões no meio acadêmico e militantes dos direitos dos animais, pauta-se a consideração de os animais não humanos serem classificados como seres com sentidos e sentimentos.

A caraterística mais usada para reconhecer a senciência, portanto, é a dor, fazendo com que o conceito da mesma seja cada vez mais utilizado em defesa dos animais não humanos, o que leva ao questionamento de o animal não humano ter direitos de proteção.

$\mathrm{Na}$ atualidade, a doutrina tem entendido que nos animais vertebrados, por possuírem sistema nervoso central, a capacidade de sentir existe, de tal modo que os animais que fazem parte do dia a dia do ser humano devem ter direitos como indivíduo. ${ }^{7}$

Em consonância com Gary L. Francione, primeiro acadêmico a lecionar sobre o tema "direito dos animais" em uma faculdade americana, a garantia dos direitos dos animais tem como critério fundamental e suficiente a senciência, complementando que:

Não há qualquer característica que sirva para distinguir os humanos dos outros animais. Qualquer atributo que possamos pensar que torna os humanos 'especiais', e assim diferentes dos outros animais, é compartilhado por algum animal não humano. ${ }^{8}$

Atualmente os conceitos acerca dos direitos dos animais vem modificando, uma vez que começam a surgir, de forma singela, jurisprudências em favor dos animais, considerando os mesmos como seres sencientes de direitos.

Recentemente o Juiz Leandro Katscharowski Aguiar, titular da 7aㅡ Vara Cível de Joinville em Santa Catarina, declinou competência para a Vara da Família, acerca de um processo de posse e

7 SINGER, Peter. Libertação Animal - O Clássico Definitivo Sobre o Movimento Pelos Direitos dos Animais e exploração animal. Editora WMF Martins Fontes, 2010.

8 FRANCIONE, Gary L. Introdução aos direitos animais. Campinas: Editora Unicamp, 2013, p. 32. 
propriedade de cão, por entender que o animal, motivo do litígio, seria um ser senciente, afirmando que:

Quem sabe se valendo da concepção, ainda restrita ao campo acadêmico, mas que timidamente começa a aparecer na jurisprudência, que considera os animais, em especial mamíferos e aves, seres sencientes, dotados de certa consciência. ${ }^{9}$

Verifica-se que o entendimento vem modificando sobre os animais não humanos, pois, se os animais conseguem receber impressões ou sensações, devem ter direitos assegurados no ordenamento jurídico.

\section{A EVOLUÇÃO HISTÓRICA DOS DIREITOS DOS ANIMAIS}

A discussão acerca dos direitos dos animais é mais antiga do que se imagina. No século VI a.C., já havia o debate questionando sobre a existência de direitos aos animais. Pitágoras informa a ideia de transmigração de almas, sendo este conceito a possibilidade de a alma passar de um corpo e residir em outro, complementando que "o homem que semeia a morte não pode colher o amor e enquanto assim agir, destruindo sem piedade os animais, nunca terá saúde, alegria e tranquilidade ao seu Espírito"10.

Por sua vez, Aristóteles debatia sobre os animais não fazerem parte da mesma escala natural do homem, ressaltando que os animais são irracionais e instrumentos para o contentamento do homem. ${ }^{11}$

9 IBDFAM. Magistrado considera cadela criatura senciente e declina competência sobre processo de posse para vara de família. Disponível em: <http://www.ibdfam.org.br/noticias/6004/Magistrado+considera+cadela+criatura+senciente+e+declina+compet $\%$ C $3 \%$ AAncia+sobre+processo+de+posse+para+vara+de+fam\%C3\%ADlia>. Acesso em: 19 out. 2016

10 LEVAI, Laerte Fernando. Direito dos Animais. O direito deles e o nosso direito sobre eles. Campos do Jordão, São Paulo: Editora Mantiqueira, 1998. p. 13-66.

11 MÓL, Samylla, VENANCIO, Renato. A proteção jurídica aos animais no Brasil: uma breve história. Rio de Janeiro: Editora FVG, 2014, p 14. 
Já na filosofia budista e em seus ensinamentos, Buda, em 500 a.C, decreta em seu primeiro mandamento: "não matarás nenhum ser vivente". ${ }^{12}$

A Bíblia retrata os animais desde seus primeiros livros:

Disse também Deus: "Encham-se as águas de seres vivos, e sobre a terra voem aves sob o firmamento do céu". Assim Deus criou os grandes animais aquáticos e os demais seres vivos que povoam as águas, de acordo com as suas espécies; e todas as aves, de acordo com as suas espécies. E Deus viu que ficou bom. Então Deus os abençoou, dizendo: "Sejam férteis e multipliquem-se! Encham as águas dos mares! E multipliquem-se as aves na terra".

Passaram-se a tarde e a manhã; esse foi o quinto dia. E disse Deus: "Produza a terra seres vivos de acordo com as suas espécies: rebanhos domésticos, animais selvagens e os demais seres vivos da terra, cada um de acordo com a sua espécie". E assim foi. Deus fez os animais selvagens de acordo com as suas espécies, os rebanhos domésticos de acordo com as suas espécies, e os demais seres vivos da terra de acordo com as suas espécies. E Deus viu que ficou bom. ${ }^{13}$

Dispõe também sobre o Homem ter domínio sobre os animais:

Então disse Deus: "Façamos o homem à nossa imagem, conforme a nossa semelhança. Domine ele sobre os peixes do mar, sobre as aves do céu, sobre os animais grandes de toda a terra e sobre todos os pequenos animais que se movem rente ao chão"14

12 CAMPOS NETO, Antonio Augusto Machado de. 0 direito dos animais. Revista da Faculdade de Direito, Universidade de São Paulo.

13 BÍBLIA. A. T. Gênesis. In: BÍBLIA. Português. Bíblia sagrada: contendo o antigo e o novo testamento. Tradução de João Ferreira de Almeida. Rio de Janeiro: Sociedade Bíblica do Brasil, 1966. Gênesis, versículo 1: 20-25.

14 BÍBLIA. A. T. Gênesis. In: BÍBLIA. Português. Bíblia sagrada: contendo o antigo e o novo testamento. Tradução de João Ferreira de Almeida. Rio de Janeiro: Sociedade Bíblica do Brasil, 1966. Gênesis, versículo 1: 26. 
Após o surgimento de Jesus, o cristianismo, bem como o Judaísmo, extinguiu em suas doutrinas o sacrifício dos animais, condenando esta prática. Salienta-se, contudo, que no Antigo Testamento condenava-se os maus tratos e sacrifício de animais.

De que me serve a mim a multidão de vossos sacrifícios, diz o Senhor? Já estou farto dos holocaustos de carneiros, e da gordura de animais cevados; nem me agrado de sangue de bezerros, nem de cordeiros, nem de bodes. ${ }^{15}$

Durante séculos se ignorava os direitos dos animais não humanos, prevalecendo a doutrina Bíblica, sendo os animais domínio do homem, servindo como ferramentas para a sobrevivência dos homens.

Em 1754, Jean-Jacques Rousseau, em seu discurso sobre a Desigualdade, rebate que os seres humanos são animais, ainda que ninguém se exima de intelecto e liberdade, e sendo os animais seres que possuem sensações, eles também deveriam participar do direito natural, tornando os homens responsáveis pelo cumprimento de alguns deveres, mais precisamente um tem o direito de não ser desnecessariamente maltratado pelo outro. ${ }^{16}$

O iluminista François-Marie Arouet, Voltaire, como ficou conhecido, traz em seu dicionário Filosófico:

A imbecilidade é afirmar que os animais são máquinas desistituídas do conhecimento e de sentimentos, agindo sempre de igual modo, e que não aprendem nada, não se aperfeiçoam e dai por diante!

15 Ibidem, Isaias, versículo 1:11.

16 ROUSSEAU, Jean Jacques. Discurso sobre a origem da desigualdade, 1754. Tradução Maria Lacerda de Moura. Edição Ridendo Castigat Mores. Edição eletrônica. Disponível em: <http//www. ebooksbrasil.org>. Acesso em: 19 out. 2016 
Talvez seja...Nesse caso esse pardalzinho que constrói o ninho em semicírculo quando o prende a uma parede, que constrói num quarto de círculo quando o faz num ângulo e em círculo num ramo de árvore - faz sempre de maneira igual? 0 cão de caça amestrado, que ensinaste a obedecer-te durante três meses, porventura não estará sabendo mais ao término desse período do que sabia no início das lições? Dedicando-te a ensinar uma melodia a um canário, será que ele repete-a logo no mesmo instante? Por acaso não levarás um certo tempo até o animalzinho a decolar? Veja como ele se engana, com frequência, e só vai se corrigindo com o tempo? Apenas por eu ser dotado de fala é que julgas que tenho sentimentos, memórias, idéias? Ora, nada te direi. No entanto, vês-me entrar em casa com um ar preocupado, aflito, andar a procurar um papel qualquer com nervosismo, abrir a secretária onde me recorda tê-lo guardando, encontrá-lo afinal, lê-lo jubilosamente. Imaginas que passei de um sentimento de aflição para outro de prazer, que sou possuidor de memória e conhecimento.

Agora, pegue esse teu raciocínio, por comparação, e transfere para aquele cão que se perdeu do dono, que entra em casa, agitado, inquieto, que desce, percorrer as casas, umas após outras, até que acaba, finalmente, por encontrar o dono de que tanto gosta no gabinete dele e ali manifesta a sua alegria pela ternura dos latidos, em pródigas carícias.

Esse animal, que excede o homem em sentimentos de amizade é pego por algumas criaturas bárbaras, que pregam-no numa mesa, dissecam-no vivo ainda para te mostrar as veias mesentéricas. No corpo deste animal encontras todos os órgãos das sensações que também existem em ti. Acaso ainda atreve-te a argumentar, se fores capaz, que a natureza colocou todos estes instrumentos do sentimento no animal para que ele não possa sentir? Dispõe de nervos para manter-se impassível? Será que não te ocorre ser por demais impertinente essa contradição da natureza? ${ }^{17}$

17 VOLTAIRE. Dicionário Filosófico. Tradução Editora Matin Claret, 2004. Capítulo 8, p. 30 e 31. 
No século XVIII, argumentava e afirmava o filósofo Jeremy Bentham que a dor animal é tão real e relevante quando a dor humana, complementando que "talvez chegue o dia em que o restante da criação animal venha a adquirir os direitos dos quais jamais poderiam ter sido privados, a não ser pela mão da tirania". ${ }^{18}$

Ainda para o autor, o que deve ser levado em consideração é a capacidade de sofrer e não a de pensar e raciocinar, pois se a habilidade da razão fosse critério, muitos seres humanos, tais como bebês e portadores de deficiências especiais, também teriam que ser tratados como coisas. A partir dessas alegações, escreveu seu mais famoso trecho sobre o assunto: "A questão não é: eles pensam? Eles falam? Mas: eles sofrem?"19

Passando para o século XIX, Arthur Schopenhauer defendeu que os animais possuem a mesma essência dos seres humanos e, acerca da falta de razão, os inclui em um sistema moral, dissertando: "Amaldiçoada toda moralidade que não veja uma unidade essencial em todos os olhos que enxergam o sol". ${ }^{20}$

No século XX, mais precisamente na década de 70, foi questionado por filósofos da Universidade de Oxford a razão pelo qual o status moral dos animais seria necessariamente inferior ao status moral dos humanos.

Devido ao discurso de Ryder, em 1975, Peter Singer, professor de Bioética na University Center for Human Values da Universidade de Princeton, lançou o livro que se tornou uma "bíblia" dos defensores dos direitos dos animais, o Libertação Animal. Porém, Singer não concede direitos morais ou legais para os animais não humanos, se baseando no utilitarismo.

18 VENANCIO, Renato. MÓL, Samylla. A proteção jurídica aos animais no Brasil - uma breve história. Editora FGV, 1. Ed. Rio de Janeiro, 2014, p. 17

19 VENANCIO, loc. cit.

20 DOVAL, Lenize Maria Soares. Direitos dos Animais: uma abordagem histórico-filosófica e a percepção de bem-estar animal. Monografia. Graduação em Veterinária. Porto Alegre: Universidade Federal do Rio Grande do Sul. Faculdade de Veterinária. 2008. Disponível em: < http://www.lume.ufrgs. $\mathrm{br} /$ bitstream/handle/10183/16438/000661804.pdf?sequence=1>. Acesso em: 19 out. 2016 
O utilitarismo é uma filosofia ética, cujo objetivo é a prescrição da ação de forma a otimizar o bem-estar do conjunto de seres sencientes. A prevenção do sofrimento é o maior valor utilitarista, ainda que se saiba o que é o sofrimento e o bem-estar, e que é nosso interesse evitar um e perseguir o outro. ${ }^{21}$

\subsection{DECLARAÇÃO UNIVERSAL DOS DIREITOS DOS ANIMAIS}

$\mathrm{Na}$ década de 70 ativistas que lutavam pela defesa dos direitos dos animais, levaram à UNESCO (Organização das Nações Unidas para a Educação, a Ciência e a Cultura) uma proposta de documento legal e de caráter internacional que visava definir conduta acerca da defesa dos animais não humanos.

Em 27 de janeiro de 1978, na Bélgica, foi proclamada pela UNESCO a Declaração Universal dos Direitos dos Animais, uma maneira de equiparar a condição de existência dos animais não humanos e os seres humanos. ${ }^{22}$

\section{A PROTEÇÃO JURÍDICA DOS ANIMAIS NÃO HUMANOS}

\subsection{A CONSTITUIÇÃO E OS ANIMAIS}

Ao longo da história é possível visualizar práticas de crueldade contra os animais, o que se fez necessário o surgimento de normas para regular e garantir a defesa e preservação não somente da flora e fauna existente, mas também dos animais.

Com a evolução da civilização, houve o surgimento de legislações de proteção aos animais não humanos, progredindo

21 DOVAL, Lenize Maria Soares. Direitos dos Animais: uma abordagem histórico-filosófica e a percepção de bem-estar animal. Monografia. Graduação em Veterinária. Porto Alegre: Universidade Federal do Rio Grande do Sul. Faculdade de Veterinária. 2008. Disponível em: < http://www.lume.ufrgs. br/bitstream/handle/10183/16438/000661804.pdf?sequence=1>. Acesso em: 19 out. 2016

22 FIO CRUZ. Declaração Universal dos Direitos dos Animais. Disponível em: <http://www.fiocruz.br/biosseguranca/Bis/infantil/direitoanimais.htm>. Acesso em: 19 out. 2016 
sempre junto com a evolução da humanidade. ${ }^{23}$ Não há o que se discutir quando o assunto é a importância da proteção do meio ambiente, uma vez que é algo necessário para a sobrevivência da humanidade. ${ }^{24}$

No Brasil, a busca pelos direitos dos animais sempre foi mais política e econômica. No Brasil colonial, a selva era vista como um grande inimigo do Homem, não havendo preocupação em preservá-la. Os animais selvagens eram comercializados tanto dentro como fora do País, e os animais domésticos serviam exclusivamente para servir ao seu dono. Como exemplo, os cachorros serviam como cães de guarda e caça, as vacas serviam para o fornecimento de carne e leite, burros eram exclusivamente para transportar coisas e pessoas e os cavalos eram usados para combate e para viagens. ${ }^{25}$

Mesmo o nosso país sofrendo mudanças políticas e organizacional, ao longo de sua história, não havia interesse na mudança da legislação sobre o tema, direito dos animais ou proteção ao meio ambiente, embora de uma maneira mais singela, durante cada década surgia algum manifesto sobre o assunto.

Em 1988 houve uma significativa modificação na legislação brasileira, com a chegada da Constituição Federal. Com a evolução da sociedade no final do século XX, fez-se necessário um repensar na situação, modificando-se os hábitos de viver. Assim, "direito é decorrente das transformações sociais e de suas demandas e as normas jurídicas são fruto da necessidade do Estado regular em conformidade com essas novas demandas da sociedade". ${ }^{26}$

${ }^{23}$ RODRIGUES, Danielle Tetü. 0 Direito \& os Animais. 2. ed. Curitiba: Editora Juruá, 2012. p. 83- 84

24 MEDEIROS, Fernanda Luiza Fontoura de. Direito dos Animais. Porto Alegre: Livraria do Advogado, 2013, p. 67

25 LEVAI, Laerte Fernando. Direito dos Animais. Porto Alegre: Livraria do Advogado, 2013, p. 26.

26 MEDEIROS, Fernanda Luiza Fontoura de. Direito dos Animais. Porto Alegre: Livraria do Advogado, 2013, p. 45. 
Para a autora Fernanda Luiza Fontoura de Medeiros, estas novas demandas conceituaram um novo Estado, o Estado Socio Ambiental e Democrático de Direito. Assim, a sociedade verificando a necessidade de existir um equilíbrio entre o progresso social e o ambiental, pensando no bem estar da futura geração, bem como na qualidade de vida atualmente, na qual tem como princípio o direito fundamental à vida e o cuidado do que os sustentam, transformou o meio ambiente, tornando-o equilibrado. ${ }^{27}$

A assistência, no Estado Democrático de Direito, alcançou as gerações futuras e, por sua vez, visou atingir outras espécies. De acordo com Silva Sanches, a solidariedade com as próximas gerações só fará mais sentido se houver solidariedade com os que sofrem atualmente, devendo haver uma complementação para que haja resultados para as próximas gerações. ${ }^{28}$

Nessa linha de raciocínio, a teoria dos direitos fundamentais não pode eliminar os animais não humanos, de modo que vem se modificando e modernizando ao ponto de admitir que os direitos fundamentais dos animais existam, não somente delimitando a força estatal em sua origem, mas também para estabelecer limites do poder um sobre o outro, em uma eficácia horizontal ${ }^{29}$.

Para Daniel Sarmento, em monografia sobre o tema diz que:

O Estado e o Direito assuem novas funções promocionais e se consolida o entendimento de que

27 MEDEIROS, Fernanda Luiza Fontoura de. Direito dos Animais. Porto Alegre: Livraria do Advogado, 2013, p. 45.

28 SILVA-SANCHES, SOLANGE S., op.cit., p 41

29 A eficácia horizontal dos direitos fundamentais: também chamada de eficácia dos direitos fundamentais entre terceiros ou de eficácia dos direitos fundamentais nas relações privadas, decorre do reconhecimento de que as desigualdades não se situam apenas na relação Estado/particular, como também entre os próprios particulares, nas relações privadas. (SARMENTO, Daniel. Direitos fundamentais e relações privadas. 2. ed. Rio de Janeiro: Lumen Juris, 2006, p. 323. Disponível em: <http://www.ambito-juridico.com.

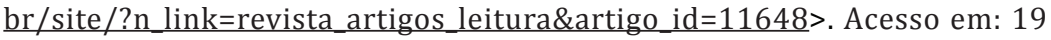
out. 2016) 
os direitos fundamentais não devem limitar o seu raio de ação às relações políticas, entre governantes e governados, incidindo também em outros campos, como o mercado, as relações de trabalho e a família. ${ }^{30}$

De acordo com o autor José Joaquim Gomes Canotilho, o direito ambiental tem uma ligação direta com a dignidade a vida, ocorrendo uma realização do princípio fundamental da dignidade da pessoa humana, no qual está previsto de forma expressa na Constituição Federal de 1988, ou seja, destaca-se como um verdadeiro protetor da dignidade da pessoa humana, indo muito mais além do que se imagina, como verdadeiro protetor da dignidade à vida de forma geral, o direito dos animais como uma proteção aos animais não humanos, é sem dúvida um direito fundamental que faz parte do ordenamento jurídico brasileiro ${ }^{31}$.

0 direito ao meio ambiente estabilizado, conforme Alexandre de Moraes, é de terceira geração, que tem como base a fraternidade e solidariedade, no qual encaixa-se na categoria dos direitos em que se destinam aos gêneros humanos e não necessariamente à proteção dos indivíduos de uma determinada região ou grupo. ${ }^{32}$

Para a autora Vania Marcia Damasceno Nogueira, pode-se buscar a Teoria da Igualdade na Consideração dos Interesses Semelhantes de Singer, legitimando-se os direitos fundamentais dos animais, como obrigação de ser-lhes dado no que for compatível. Os animais requerem um direito fundamental que é o direito à

30 SARMENTO, Daniel. Direitos fundamentais e relações privadas. 2. ed. Rio de Janeiro: Lumen Juris, 2006, p. 323. Disponível em: <http://www.ambito-juridico.com.br/site/?n_link=revista_artigos_leitura\&artigo_id=11648>. Acesso em: 19 out. 2016

31 CANOTILHO, José Joaquim Gomes; LEITE, José Rubens Morato (Org.). Direito Constitucional Ambiental Brasileiro. 3. ed. São Paulo: Editora Saraiva, 2010, p. 118.

32 MORAES, Alexandre de. Direito Constitucional. 24. ed. São Paulo: Editora Atlas S.A., 2009, p. 31-32. 
vida, o que não significa que devam requerer viver com luxos extremos, receber heranças e usar joias caras. ${ }^{33}$

A nossa Constituição Federal, em seu artigo 225, prevê e admite que os animais não humanos são munidos de emoção e sentimentos, forçando o Estado e à sociedade o dever de preocupar-se com a vida, a liberdade e integridade física dos animais.

Art. 225. Todos têm direito ao meio ambiente ecologicamente equilibrado, bem de uso comum do povo e essencial à sadia qualidade de vida, impondose ao Poder Público e à coletividade o dever de defendê-lo e preservá- lo para as presentes e futuras gerações.

$\S 1$ - Para assegurar a efetividade desse direito, incumbe ao Poder Público:

VII - proteger a fauna e a flora, vedadas, na forma da lei, as práticas que coloquem em risco sua função ecológica, provoquem a extinção de espécies ou submetam os animais a crueldade. ${ }^{34}$

Bem como é função do Ministério Público:

Art. 129. São funções institucionais do Ministério Público:

(...)

III - promover o inquérito civil e a ação civil pública, para a proteção do patrimônio público e social, do meio ambiente e de outros interesses difusos e coletivos; ${ }^{35}$

33 ARRAES, Vania Marcia Damasceno Nogueira. Direitos fundamentais dos animais a construção jurídica de uma titularidade para além dos seres humanos. Editora, 2012, p. 280.

34 BRASIL. Constituição (1988). Constituição Federal do Brasil de 1988. Disponível em: <http://www.planalto.gov.br/ccivil_03/Constituicao/Constituicao. htm>. Acesso em: 22 out. 2016.

35 BRASIL. Constituição (1988). Constituição Federal do Brasil de 1988. Disponível em: <http://www.planalto.gov.br/ccivil_03/Constituicao/Constituicao. htm>. Acesso em: 22 out. 2016. 
Apesar do Brasil vedar de forma expressa na Constituição Federal a crueldade com os animais, é utilizado os animais para vários fins sem qualquer controle, indo na contra-mão das várias legislações. Cabe ressaltar que o não cumprimento dessas legislações de maneira mais eficaz, não quer dizer que o direito não exista, devendo ser garantido pelo judiciário. ${ }^{36}$

Assim, os direitos dos Animais é um ramo do direito relativamente recente, que pode ser ligado aos direitos fundamentais, que visa mostrar o direito fundamental, bem como os direitos dos animais. Desse raciocínio diferenciado, se traz para dentro do direito uma estrutura de direito e dever, firmado na terceira dimensão dos direitos fundamentais, ou seja, no direito de solidariedade.

0 entendimento jurídico sobre os animais não humanos vem se modificando, de forma lenta, mas mostrando que já está presente na atual realidade da sociedade, não somente no Brasil, mas no mundo.

Conceitua Bráulio Lopes, professor de legislação ambiental no Centro Técnico Educacional SOMARTI, ser o direito fundamental um conjunto de direitos e garantias imprescritíveis e invioláveis do homem que visa o respeito à sua dignidade, baseado na proteção do Estado garantidor de condições dignas de vida no qual, dentro dela se encontra a liberdade, saúde, educação entre outros. ${ }^{37}$

Os direitos dos animais e sua proteção estará sempre ligado diretamente a defesa do meio ambiente, entretanto, para que as mudanças comecem a acontecer de forma mais visível e concreta, deve-se haver uma mudança de paradigma no qual reconhece-

36 FELIPE, S.T. Dos direitos morais aos direitos constitucionais: Para além do especismo elitista e eletivo. Salvador: Instituto de Abolicionismo Animal, 2007. Revista Brasileira de Direito Animal. v. 2, n.1, jun/2007.

37 LOPES, Bráulio. Direito com cultura. Disponível em: < (https://direitocomcultura.wordpress.com/2010/08/13/art-225-vii-\%E2\%80\%93-constituicaofederal-animais-tem-direitos-fundamentais-ou-sao-tutelados-pela-constituicao/>. Acesso em: 19 out. 2016. 
se os animais não humanos como seres de direito, fazendo-se necessário uma mudança, identificando a teoria de direitos fundamentais específica aos animais não humanos. ${ }^{38}$

\subsection{O ORDENAMENTO JURÍDICO INFRACONSTITUCIONAL E OS ANIMAIS}

No Plano Infraconstitucional, a primeira vez que o Brasil ouviu falar de uma legislação de proteção aos animais foi em 1934, com o então Presidente Getúlio Vargas, que promulgou o Decreto nำ 24.645, no qual, estabelecia medidas de proteção aos animais não humanos, tornando-se uma legislação pioneira acerca dos direitos aos animais.

Art. $1^{\text {o }}$ - Todos os animais existentes no País são tutelados do Estado. (...)

Art. $3^{\circ}$ - Consideram-se maus tratos: I - praticar ato de abuso ou crueldade em qualquer animal; (...) VI - não dar morte rápida, livre de sofrimento prolongados, a todo animal cujo extermínio seja necessário para consumo ou não. ${ }^{39}$

Em 3 de outubro de 1941, com a criação da Lei das Contravenções Penais, o Presidente Getúlio Vargas manteve a posição de proteção aos animais, não permitindo, no artigo 64, da referida lei, a crueldade contra animais não humanos.

Art. 64. Tratar animal com crueldade ou submetê-lo a trabalho excessivo:

38 ARRES, Vania Marcia Damasceno Nogueira. Direitos fundamentais dos animais a construção jurídica de uma titularidade para além dos seres humanos. Editora, 2012, p. 282.

39 BRASIL. Decreto 24.645, de 10 de julho de 1934. Disponível em: <http:// www.planalto.gov.br/ccivil_03/decreto/1930-1949/D24645.htm>. Acesso em: 19 out. 2016. 
Pena - prisão simples, de dez dias a um mês, ou multa, de cem a quinhentos mil réis. ${ }^{40}$

Devido a criação da Constituição Federal de 1988, houve um grande avanço para a proteção dos animais, como a editada Lei $\mathrm{n}$ 9605, em 1998, Lei de Crimes Ambientais, passando de contravenção para crime, sendo punido com detenção de seis meses a um ano, quem maltratar, matar, perseguir, caçar, animais silvestres.

Art. 32. Praticar ato de abuso, maus-tratos, ferir ou mutilar animais silvestres, domésticos ou domesticados, nativos ou exóticos: Pena - detenção, de três meses a um ano, e multa. ${ }^{41}$

Ao longo da história é possível visualizar práticas de crueldade contra os animais, o que se fez necessário o surgimento de normas para regular e garantir a defesa e preservação não somente da flora e fauna existentes, mas também dos animais.

Com a evolução da civilização, houve o surgimento de legislações de proteção aos animais não humanos, progredindo sempre junto com a evolução da humanidade. Então, não há o que se discutir quando o assunto é a importância da proteção do meio ambiente, uma vez que é algo necessário para a sobrevivência da humanidade. ${ }^{42}$

40 BRASIL. Decreto Lei 3688, de 03 de outubro de 1941. Disponível em: < http:// www.planalto.gov.br/ccivil_03/decreto-lei/Del3688.htm>. Acesso em: 19 out. 2016.

41 BRASIL. Lei 9.605, de 12 de fevereiro de 1998. Disponível em: <http://www. planalto.gov.br/ccivil_03/leis/L9605.htm>. Acesso em: 19 out. 2016.

42 MEDEIROS, Fernanda Luiza Fontoura de. 0 Direito \& os Animais. 2. ed. Curitiba: Editora Juruá, 2012. p. 84-85. 134. Direito dos Animais. Porto Alegre: Livraria do Advogado, 2013, p. 67 


\subsection{PRINCÍPIO DA DIGNIDADE À VIDA APLICADA AOS ANIMAIS NÃO HUMANOS}

De acordo com a autora Vania Márcia Damasceno Nogueira, o princípio da dignidade à vida é o mais indicado para que possa se fundamentar o tratamento mais adequado e mais ético aos seres de espécies diferente dos seres humanos.

A doutrina vem trazendo outros elementos que são fundamentais, além do princípio da dignidade à vida, como por exemplo valores intrínsecos, interesses, racionalidade prática, a compaixão e o mais importante, a senciência. ${ }^{43}$

Embora quando a Constituição Federal dispõe sobre "todos terem direito ao meio ambiente ecologicamente equilibrado", bem como em seu inciso VII, $\$ 1^{\circ}$, proíba os maus tratos, seria uma contradição os humanos tratarem os animais não humanos como simples objetos ou coisas.

Os maus tratos aos animais geram um sentimento de compaixão no ser humano, pois, de alguma maneira, trata-se da vida do animal não humano, demonstrando que o indivíduo atribui importância diferenciada com os animais, o que não aconteceria com uma cadeira. ${ }^{44}$

Os animas não humanos não devem mais ser consideradas coisas, mesmo que ainda exista uma porcentagem de pessoas que os tratam como objetos, não conseguindo sentir compaixão por uma coisa. ${ }^{45}$

${ }^{43}$ ARRAES, Vania Marcia Damasceno Nogueira. Direitos fundamentais dos animais a construção jurídica de uma titularidade para além dos seres humanos. Editora, 2012, p. 301.

44 Ibidem, p. 302

45 ARRAES, Vania Marcia Damasceno Nogueira. Direitos fundamentais dos animais a construção jurídica de uma titularidade para além dos seres humanos. Editora, 2012, p. 302 
4.4 ANÁLISE E COMPARATIVO DO ARTIGO 5 DA CONSTITUIÇÃO APLICADA AOS ANIMAIS NÃO HUMANOS

De acordo com o art. 5ำ da Constituição Federal, todos somos iguais perante a lei.

Art. 5o Todos são iguais perante a lei, sem distinção de qualquer natureza, garantindo-se aos brasileiros e aos estrangeiros residentes no País a inviolabilidade do direito à vida, à liberdade, à igualdade (...)

Segundo Vânia Marcia Damasceno Nogueira, o que faz os humanos serem iguais uns aos outros é justamente o fato de serem sujeitos de uma vida, os interesses que possuem em qualidade de vida e liberdade. Bem estar é algo que todos buscam, tornando-se aptos de terem direitos que venham a garantir esses interesses. ${ }^{46}$

0 fato de "ser sujeito de uma vida", faz com que todos se tornem iguais conforme a habilidade de ter status moral, das quais a igualdade tenha sentido. ${ }^{47}$

Partindo do pressuposto que os animais também podem fazer parte desta classificação, ou seja, também são "sujeitos de uma vida", pode-se afirmar que possuem direitos a dignidade e ao respeito.

Não se pode, portanto, tratar um animal não humano como se fosse um objeto por ele ser supostamente inferior ao indivíduo, a partir do momento que os animais possuem vida, já há garantia ao direito de serem iguais aos humanos. ${ }^{48}$

É necessário lembrar que o maior bem é a vida, não sendo possível uma vida valer mais que outra, inferior ou superior. Maltratar um animal não humano, tendo como argumento a sua inferioridade intelectual, comparando-os com os seres humanos, é insultar a igualdade a vida. ${ }^{49}$

46 Ibidem, p. 304

47 SARLET, Ingo Wolfgang; FENSTERSEIFER, Tiago, op. cit. p. 175-205

48 ARRES, op. cit., p. 304

49 Ibidem, p. 304 
Há uma grande diferença entre os animais e os humanos que se precisa destacar. Os primeiros matam outros animais, pois assim mantém o funcionamento da cadeia alimentar e o equilíbrio ecológico. Os humanos, ao contrário, quando matam outros animais fazem por esporte, por prazer, para embelezar o corpo, satisfazer o paladar, mas muitas vezes, não é por necessidade. Os humanos também matam membros da sua própria espécie, mas imbuídos pela ganância, ambição, inveja e sede de poder. Entretanto, não somente matam, a história demostra a tendência humana à tortura, o que se observa nos campos de concentrações e nas prisões. ${ }^{50}$

A declaração Universal dos Diretos dos animais, traz em seu artigo 1ํㅡㄹ a garantia de que todos os animais são iguais, da mesma forma que a Constituição Federal garante aos humanos. Possuindo, assim, os animais não humanos, o mesmo valor que os humanos. ${ }^{51}$

Para Gabriela Dias Oliveira, "se as filosofias moral e política modernas proclamam o princípio da igualdade como fundamento da legislação humana, é de se indagar a partir de que critérios os iguais são mensurados". ${ }^{52}$

\section{RELIGIÃO E OS ANIMAIS}

Durante séculos os animais faziam parte direta e ativa da religião, em cada cultura, o animal tinha um significado. No Egito Antigo além de seus deuses serem parte humano e parte animal, como a Deusa Bastet, ligada a fertilidade, sua imagem tinha forma de um gato. 0 animal para os egípcios era considerado sagrado, pois acreditavam que o felino trazia boa sorte. ${ }^{53}$

50 DUTRA, Valeria de Souza Arrufa, op. cit.

51 ARRAES, Vania Marcia Damasceno Nogueira. Direitos fundamentais dos animais a construção jurídica de uma titularidade para além dos seres humanos. Editora, 2012, p. 305

52 OLIVEIRA, Gabriela Dias. Animais humanos e não humanos de Tom Regan. Ethic@, Florianópolis, v.3, n.3, p. 283-299, dez. 2004. Disponível em: <http:// www.cfh.ufsc.b/rthic@/capa73.htm>. Acessado em: 19 out. 2016

53 DOVAL, Lenize Maria Soares. Direitos dos Animais: uma abordagem histórico-filosófica e a percepção de bem-estar animal. Porto Alegre, 2008, p. 28 
Havia também na cultura grega, referência de animais em seus Deuses, como por exemplo Athena, Deusa da Sabedoria que era retratada com uma coruja em suas mãos ou ombros. Assim, a coruja para os gregos era símbolo de sabedoria, simbologia usada até hoje na modernidade. Ainda na Grécia Antiga, talvez a figura mais conhecida da história, o Centauro, meio homem e meio cavalo. ${ }^{54}$

Na cultura chinesa, existe uma grande simbologia com os animais, eles fazem parte de seu calendário, cada ano corresponde a um animal que tem um significado, bem como os Dragões, como figuras mitológicas que representam sorte e poder. 0 dragão amarelo representa o Imperador da china, por exemplo. 0 pato é um animal usado em casamentos, uma vez que eles acreditam que represente felicidade e fidelidade. ${ }^{55}$ Salienta-se que, no mesmo país, acontece o festival de carne de cachorro, sendo responsável por grandes manifestações contra a prática que revolta o mundo. ${ }^{56}$

Na Índia, a vaca é considerada um animal sagrado e não é consumido como alimento.

No Brasil existe uma grande discussão acerca de sacrifícios de animais em cultos religiosos. O Ministério Público do Estado do Rio Grande do Sul recorreu da decisão da aprovação de um projeto de Lei, após o ex-deputado estadual Edson Portilho, apresentar e conseguir aprovação no Legislativo do Projeto de Lei no qual, incluía um parágrafo no Código Estadual de Proteção aos Animais, garantindo às religiões "afro" a prática de sacrifício de animais em rituais.

54 DOVAL, Lenize Maria Soares, op cit, p. 29.

55 CHINA NA MINHA VIDA. Animais e as crenças chinesas. Disponível em: $<\mathrm{h}-$ ttps://chinanaminhavida.com/2011/06/19/animais-e-as-crencas-chinesas/> Acesso em: 19 out. 2016

56 G1. Sob protestos, China realiza festival de carne de cachorro. Disponível em: < http://g1.globo.com/mundo/noticia/2016/06/sob-protestos-china -realiza-festival-de-carne-de-cachorro.html>. Acesso em: 19 out. 2016 
Aprovado projeto pelo então Governador do Estado, Germano Rigotto, com algumas ressalvas, como por exemplo ser legal que os sacrifícios envolvessem animais cujo abate visassem ao consumo humano, bem como a ilegalidade a qualquer tipo de maus tratas aos animais, como morte lenta e dolorosa aos animais. ${ }^{57}$

Porém o MPRS, alegando inconstitucionalidade no Projeto de Lei, não obteve êxito em seu pleito, interpondo uma ADIn em $2006 .^{58}$ O Supremo Tribunal Federal determinou a constitucionalidade da norma que permitia o sacrifício de animais em rituais religiosos através do Recurso Extraordinário 494601, onde o MPRS alegou que era uma afronta ao princípio isonômico e a natureza laica brasileira. Entretanto, o STF indeferiu o pedido de provimento do Recurso do MPRS, tornando vigente a Lei no Estado do Rio Grande do Sul. ${ }^{59}$

A jurisprudência:

CONSTITUCIONAL. AÇÃO DIRETA. SACRIFÍCIO RITUAL DE ANIMAIS. CONSTITUCIONALIDADE. 1. Não é inconstitucional a Lei 12.131/04-RS, que introduziu parágrafo único ao art. 2.ำ da Lei 11.915/03-RS, explicitando que não infringe ao "Código Estadual de Proteção aos Animais" o sacrifício ritual em cultos e liturgias das religiões de matriz africana, desde que sem excessos ou crueldade. Na verdade, não há norma que proíba a morte de animais, e, de toda sorte, no caso a liberdade de culto permitiria a prática. 2. AÇÃO JUL-

57 PREFEITURA DE PORTO ALEGER. Sacrifício de animais em rituais religiosos: o legado do retrocesso. Disponível em:<http://www2.portoalegre. rs.gov.br/seda/default.php?reg=737\&p_secao=32>. Acesso em: 19 out. 2016 MINISTÉRIO PÚBLICO DO RIO GRANDE DO SUL. Ações Diretas e Incidentes de Inconstitucionalidade no TJ/RS. Disponível em:<https://www.mprs. mp.br/adins/mostra_processo?numero=10824\&ano=2004> Acesso em: 19 out. 2016.

59 SUPREMO TRIBUNAL FEDERAL. Sacrifício de animais em rituais religiosos será discutido pelo STF. Disponível em:<http://www.stf.jus.br/portal/cms/ verNoticiaDetalhe.asp?idConteudo=68292> Acesso em: 19 out. 2016. 
GADA IMPROCEDENTE. VOTOS VENCIDOS. (Ação Direta de Inconstitucionalidade № 70010129690, Tribunal Pleno, Tribunal de Justiça do RS, Relator: Araken de Assis, Julgado em 18/04/2005) ${ }^{60}$

\section{Conforme entendimento do Supremo Tribunal Federal, por Bruna Correa: \\ O Supremo Tribunal Federal estabelece o sacrifício animal não-imprescindível como um crime infracio- nal. Além disso, por mais digno que seja o ritual, aos animais não estão sendo válidas as normas da Lei de Crimes Ambientais, que proíbem a mutilação, o golpeamento ou qualquer outro ato de crueldade. Também não há controle sanitário e eles, não são se- dados, o que igualmente agride as normas federais. ${ }^{61}$}

Mesmo o Supremo Tribunal Federal estabelecendo o sacrifício de animais como algo legítimo, este entendimento vai contra a Lei Federal n‥ 9.605 de $1998^{62}$ que define como crime federal o abandono e os maus tratos praticado contra qualquer animal.

Artigo 32 da Lei Federal nํ. 9.605/98

É considerado crime praticar ato de abuso, maus-tratos, ferir ou mutilar animais silvestres, doméstico ou domesticados, nativos ou exóticos. Pena - Detenção de 3 (três) meses a 1 (um) ano e multa.

Parágrafo $1^{\circ}$. - Incorre nas mesmas Penas quem realiza experiência dolorosa ou cruel em animais vivos, ainda que para fins didáticos ou científicos, quando existirem recursos alternativos.

Parágrafo $2^{\circ}$. - A Pena é aumentada de 1 (um) terço a 1 (um) sexto, se ocorrer a morte do(s) animal(s)."

60 BRASIL. Tribunal de Justiça do Rio Grande do Sul. ADI: 70010129690 RS. Relator: Araken de Assis. Porto Alegre, 18 de abril de 2005.

61 CORREA, Bruna. Sacrifício de animais em rituais religiosos: o legado do retrocesso.

62 BRASIL. Código Civil. Disponível em:<http://www.planalto.gov.br/ccivil_03/ leis/L9605.htm>. Acesso em: 19 out. 2016. 
Ademais, trata-se crime o abandono de animais, previsto no nosso Código Penal em seu artigo $164^{63}$ :

Art. 164 - Introduzir ou deixar animais em propriedade alheia, sem consentimento de quem de direito, desde que o fato resulte prejuízo:

Pena - detenção, de quinze dias a seis meses, ou multa.

\section{POLÍTICAS PÚBLICAS QUE GARANTEM DIREITO AOS ANIMAIS NÃO HUMANOS}

Para a garantia dos direitos dos animais, o município de Porto Alegre, através de ações do Gabinete da Primeira dama Regina Becker, conhecida por seus trabalhos em defesa dos animais não humanos, criou a Secretaria Especial de Direito dos Animais SEDA $^{64}$, pioneira na história do Brasil, através da Lei Municipal 11.101/2011 e regulamentada pelo Decreto 17.190/2011, da secretaria da Prefeitura de Porto Alegre. A lei foi criada para:

Estabelecer e executar políticas públicas destinadas à saúde, proteção, defesa e bem-estar animal em Porto Alegre. Os objetivos estratégicos da SEDA estão pautados em ações que visam reduzir os maus tratos aos animais, controlar o crescimento populacional de cães e gatos, reduzir significativamente a população animal abandonada, consolidar na população de Porto Alegre a incorporação de valores relacionados à guarda responsável de animais. ${ }^{65}$

63 BRASIL. Decreto-Lei no 2.848, de 7 de dezembro de 1940. Disponível em:< http://www.planalto.gov.br/ccivil_03/decreto-lei/Del2848compilado.htm>. Acesso em: 19 out. 2016

64 PONTES, Bianca Calçada. SEDA: exemplo de políticas públicas para animais domésticos no município de Porto Alegre - Coleção CEJA. OAB/RS, 2012. Editora Buqui, p. 81-106

65 PREFEITURA DE PORTO ALEGRE. A SEDA. Disponível em:<http://www2. portoalegre.rs.gov.br/seda/default.php?p_secao=7>. Acesso em: 19 out. 2019 
A SEDA tem o dever fundamental de proteger os animais não humanos no município de Porto Alegre, incluindo em seu programa de políticas públicas a formação desta secretaria, dos quais o seu foco é um princípio constitucional que iguala os animais não humanos como seres de direitos devendo sua tutela ser do Estado. ${ }^{66}$

No dia 19/10/2016, para os que defendem os direitos dos animais, houve mais uma vitória: em Porto Alegre foi inaugurado o Primeiro Hospital Público Veterinário do Estado.

Graças a doações particulares, a união entre servidores, o judiciário e as prefeituras de Porto Alegre e de Viamão a Unidade de Saúde Animal Victória foi entregue a cidade, e terá a SEDA como guardiã do empreendimento. Neste local até 200 animais poderão ficar internados e o espaço de triagem será para 120 animais. ${ }^{67}$

Pensando na defesa dos animais não humanos, por serem seres sencientes outras cidades estão seguindo o exemplo da SEDA de Porto Alegre, como a cidade de São Leopoldo/RS que em 2013 começou a discutir a criação de uma Secretaria no município que cuide dos interesses dos animais, bem como a cidade de Recife, também em 2013, que iniciou análise para criação de secretaria especializada nos direitos dos animais em Pernambuco: ${ }^{68}$

Para o novo secretário, a decisão do prefeito de Recife, Geraldo Julio em criar a secretaria foi um avanço nesta nova e contemporânea política pública, ao lado de Porto Alegre e Rio de janeiro, pioneiras em implantar estas unidades em suas

66 PONTES, op. cit., p. 106

${ }^{67}$ GLAMORAMA. Bilionário brasileiro inaugura no Sul hospital público para animais. Disponível em: <http://glamurama.uol.com.br/bilionario-brasileiro-inaugura-no-sul-hospital-publico-para-animais/> Acesso em: 19 out. 2016

68 PREFEITURA DE PORTO ALEGRE. São Leopoldo discutirá a criação de uma Secretaria Especial dos Direitos Animais. Disponível em: < http://www2. portoalegre.rs.gov.br/seda/default.php?reg=810\&p_secao=32>. Acesso em: 19 out. 2016 
administrações. "Muito me honra ter plantado esta Secretaria no programa de governo do atual prefeito e ter sido convidado para assumi-la. Meu coração está repleto de alegria e gratidão a Deus. ${ }^{69}$

A passos pequenos, porém grandiosos para os defensores dos animais, alguns países Europeus entre outros países do mundo, vem modificando o seu ordenamento jurídico, passando os animais de meros objetos para seres sencientes que possuem direitos e garantias, como por exemplo a França $\mathrm{a}^{70}$, a Nova Zelândia ${ }^{71}$ e Colômbia ${ }^{72}$ alteraram seus códigos civis, reconhecendo os animais não humanos como seres sencientes e com direitos. Ainda, na Alemanha, Áustria e Suíça, mesmo seus códigos sendo do século passado, os países modificaram suas leis classificando os animais em uma nova categoria, reconhecendo que os animais não humanos, não são objetos, mas sim animais como sujeitos de direitos. ${ }^{73}$

69 VIDAL, Rodrigo. Secretário da Secretaria Executiva dos Direitos Animais do Recife. Disponível em:<http://www.anda.jor.br/09/01/2013/recife-pe-segue -os-passos-de-porto-alegre-rs-e-cria-sua-seda> . Acesso em: 19 out. 2016.

70 ANDA. Em decisão histórica França altera Código Civil e reconhece animais como seres sencientes. Disponível em: <https://www.google. com.br $/$ url? sa=t\&rct=j\&q=\&esrc=s\&source=web\&cd=1\&cad=rja\&uact $=8 \&-$ ved=0ahUKEwjoq608l_TPAhVKGZAKHQWFBWgQFggcMAA\&url=http $\% 3 A \%$ 2F\%2Fwww.anda.jor.br\%2F03\%2F02\%2F2015\%2Fdecisao-historica-franca-altera-codigo-civil-reconhece-animais-seres-sencientes\&usg=AFQjCNEIiJXE_zZoQNuDKvxiFVy-ErX4Tw>. Acesso em: 19 out. 2016.

71 OLHAR ANIMAL. Nova Zelândia reconhece legalmente os animais como seres sencientes. Disponível em:<http://olharanimal.org/nova-zelandia -reconhece-legalmente-os-animais-como-seres-sencientes/> Acesso em: 19 out. 2016

72 ZH NOTÍCIAS. Maltratar animais na Colômbia provocará prisão. Disponível em:<http://zh.clicrbs.com.br/rs/noticias/noticia/2016/01/maltratar-animaisna-colombia-provocara-prisao-4946031.html>. Acesso em: 19 out. 2016

73 ARRAES, Vania Marcia Damasceno Nogueira. Direitos fundamentais dos animais a construção jurídica de uma titularidade para além dos seres humanos. Editora, 2012, p. 316 
Na Noruega, buscando uma forma de lutar contra os maus tratos aos animais não humanos, o país decidiu pela criação de uma polícia especializada e dedicada a defesa dos animais. ${ }^{74}$

A Holanda tornou-se referência por conquistar um título muito importante para a Defesa dos animais não humanos, através de um plano de governo, no qual fundamentou-se em 4 pilares: leis mais rígidas para quem abandona animais, punição com multas de milhares de Euros, campanhas de conscientização e castrações e, por fim, altas taxas de impostos para aqueles que preferem comprar animais de raça. ${ }^{75}$

Desse modo, a Holanda tornou-se o primeiro país no mundo sem cães abandonados e sem a necessidade de sacrificar animais para chegar nesta marca, evitando a reprodução de cães em situação de rua, bem como incentivando a população a adotar animais abandonados. Cabe ressaltar que atualmente, no mundo é estimado que exista 600 milhões de cachorros vivendo em situação de rua.

No Brasil, houve em 2014 uma enquete na plataforma do Senado perguntando: "Você é a favor ou contra o projeto que proíbe a utilização de animais na pesquisa de desenvolvimento de produtos cosméticos e de higiene pessoal? ". O Resultado desta pesquisa mostrou que $84,2 \%$ dos votos eram a favor da proibição e $15,8 \%$ contra a proibição. ${ }^{76}$

74 SCIENCES ET AVENIR. Disponível em:<http://www.sciencesetavenir.fr/ animaux/en-norvege-les-animaux-ont-leur-propre-police_100754> Acesso em: 19 out. 2016

75 HYPENESS. Holanda se torna o primeiro país sem cães abandonados - e não precisou sacrificar nenhum. Disponível em:http://www.hypeness.com. br/2016/07/holanda-se-torna-o-1o-pais-sem-caes-abandonados-e-semsacrificar-animal-algum/. Acesso em: 19 out. 2016

76 SENADO FEDERAL. Utilização de animais na pesquisa e desenvolvimento de produtos cosméticos e de higiene pessoal. Disponível em: <https:// www12.senado.leg.br/institucional/datasenado/enquetes/internautas -apoiam-projeto-que-proibe-o-uso-de-animais-em-testes-de-produtos-cosmeticos-e-de-higiene-pessoal>. Acesso em: 19 out. 2016 
Este projeto segue, em andamento no Senado, e atualmente encontra-se CCT - Comissão de Ciência, Tecnologia, Inovação, Comunicação e Informática para apreciação. ${ }^{77}$

Em Porto Alegre, já existe uma proibição acerca da utilização dos animais não humanos, em São Paulo também foi aprovado uma Lei no mesmo sentido, após a invasão ao instituto Royal para salvar Beagles que seriam utilizados em pesquisas. ${ }^{78}$

O Brasil vem se modificando, e buscando o melhor para os animais não humanos, e igualando-os ao status jurídicos, como a decisão do STJ que decidiu manter duas araras no ambiente doméstico onde foram criadas há mais de 20 anos, não havendo sinas de maus tratos:

RECURSO ESPECIAL № 1.425 .943 - $\mathrm{RN}$ (2013/0414637-8)

RELATOR : MINISTRO HERMAN BENJAMIN

RECORRENTE : INSTITUTO BRASILEIRO DO MEIO AMBIENTE E DOS RECURSOS NATURAIS RENOVÁVEIS - IBAMA

REPR. POR : PROCURADORIA-GERAL FEDERAL RECORRIDO : MOISES HONORATO DE OLIVEIRA ADVOGADO : FRANCISCO GERVÁSIO LEMOS DE SOUSA E OUTRO (S)

EMENTA

ADMINISTRATIVO E AMBIENTAL. OFENSA AO ART. 535 DO CPC NÃO DEMONSTRADA. APREENSÃO DE ARARAS. ALEGADA VIOLAÇÃO DO ART. 1ำ DA LEI 5.197/1997 E DO ART. 25 DA LEI 9.605/1998. INEXISTÊNCIA.

1. Hipótese em que o recorrido ajuizou Ação Ordinária com Pedido de Tutela Antecipada contra ato

7 SEnAdo federal. Projeto de Lei da Câmara no 70, de 2014. Disponível em:<http://www25.senado.leg.br/web/atividade/materias/-/materia/118217>. Acesso em: 19 out. 2016

78 G1. Lei proíbe uso de animais em testes de cosméticos em Porto Alegre. Disponível em:<http://g1.globo.com/rs/rio-grande-do-sul/noticia/2015/09/ lei-proibe-uso-de-animais-em-testes-de-cosmeticos-em-porto-alegre.html>. Acesso em: 19 out. 2016 
de apreensão de duas aves (uma arara vermelha e uma arara canindé) que viviam em sua residência havia mais de vinte anos.

2. O Tribunal de origem, após análise da prova dos autos, constatou que "as aves já estavam em convívio com a família por longo período de tempo, com claros sinais de adaptação ao ambiente doméstico" (fl. 252, e-STJ), "a reintegração das aves ao seu habitat natural, conquanto possível, possa ocasionar-lhes mais prejuízos do que benefícios" (fl. 252, e-STJ), "as aves viviam soltas no quintal (...) não sofriam maus tratos e recebiam alimentação adequada" (fl. 252, e-STJ), "a dificuldade que esses animais enfrentarão para adaptarem-se ao ambiente natural, pondo em xeque até o seu êxito" (fl. 253, e-STJ) e "já convivem há mais de 20 anos com o demandante" (fl. 254, e-STJ).

3. O Tribunal local julgou integralmente a lide e solucionou a controvérsia, tal como lhe foi apresentada.

4. Inexiste violação do art. 1ำ da Lei 5.197/1997 e do art. 25 da Lei 9.605/1998 no caso concreto, pois a legislação deve buscar a efetiva proteção dos animais. Após mais de 20 anos de convivência, sem indício de maltrato, é desarrazoado determinar a apreensão de duas araras para duvidosa reintegração ao seu habitat.

5. Registre-se que, no âmbito criminal, o art. 29 , § $2^{\circ}$, da Lei 9.065/1998 expressamente prevê que, "no caso de guarda doméstica de espécie silvestre não considerada ameaçada de extinção, pode o juiz, considerando as circunstâncias, deixar de aplicar a pena".

6. Recurso Especial não provido.

ACÓRDÃO

Vistos, relatados e discutidos os autos em que são partes as acima indicadas, acordam os Ministros da SEGUNDA Turma do Superior Tribunal de Justiça: "A Turma, por unanimidade, negou provimento ao recurso, nos termos do voto do (a) Sr (a). Ministro (a)-Relator (a)." Os Srs. Ministros Og Fernandes, 
Mauro Campbell Marques (Presidente), Assusete Magalhães e Humberto Martins votaram com o Sr. Ministro Relator.

Brasília, 02 de setembro de 2014 (data do julgamento). ${ }^{79}$

Ainda, no Direito de Família, já vem mudando o entendimento dos magistrados acerca dos animais inseridos na rede familiar, partindo da ideia de que o animal não humano é um ser senciente e não mais um objeto como o código civil Brasileiro vigente afirma. ${ }^{80}$

Art. 82. São móveis os bens suscetíveis de movimento próprio, ou de remoção por força alheia, sem alteração da substância ou da destinação econômico-social. ${ }^{81}$

Embora o artigo acima, fale sobre os animais como bens suscetíveis de movimento próprio, animais não humanos vem se igualando, juridicamente, há filhos, uma vez que um casal que está em processo de divórcio, discute a guarda de seus animais de estimação.

Para Maria Berenice Dias, está se tornando frequente, a questão do divórcio de um casal que possui animais de estimação, e a discussão sobre a guarda dos mesmos, restando a guarda para um deles e para o outro é garantido o direito de visita. ${ }^{82}$

79 JUS BRASIL. RECURSO ESPECIAL n. 1.425.943 - RN do STJ. Disponível em:<http://www.jusbrasil.com.br/diarios/documentos/141119804/recurso-especial-n-1425943-rn-do-stj>. Acesso em: 19 out. 2016

80 ARRAES, Vania Marcia Damasceno Nogueira. Direitos fundamentais dos animais a construção jurídica de uma titularidade para além dos seres humanos. Editora, 2012, p. 316

81 BRASIL. LEI 10.406, de 10 de janeiro de 2002. Disponível em:<http:// www.planalto.gov.br/ccivil_03/leis/2002/L10406compilada.htm>. Acesso em: 19 out. 2016.

82 DIAS, Maria Berenice. Alimentos aos Bocados. São Paulo: Editora Revista dos Tribunais, 2013, p. 126. 
O caso que mais teve repercussão no Brasil, sobre o tema acima, foi o caso da cadelinha chamada Linda, cujo o Juiz Leandro Katscharowski Aguiar, titular da 7aㅡ Vara Cível da comarca de Joinville, declinou competência, de um processo no qual havia uma disputa pela cadelinha que o casal tinha, para a vara de família, por entender que: ${ }^{83}$

Penso que a questão de fundo versa, necessariamente, sobre a declaração, ainda que incidental, da guarda do animal, cuja discussão, por sua vez, envolve o direito de família, "mais do que justo" que os magistrados das varas da Família avaliem a questão, uma vez que são "muito mais sensíveis às agruras do dos conflitos familiares, Quem sabe se, valendo da concepção, ainda restrita ao campo acadêmico, mas que timidamente começa aparecer na jurisprudência , que considera os animais, em especial mamíferos e aves, seres sencientes, dotados de de certa consciência. ${ }^{84}$

No Rio Grande do Sul também já existe disputas semelhantes:

RECURSO INOMINADO. COMPETÊNCIA. DISPUTA ENVOLVENDO UMA CADELA DA RAÇA YORK SHIRE. PEDIDO QUE NÃO ENVOLVE DISSOLUÇÃO DE UNIÃO ESTÁVEL OU PARTILHA DE OUTROS BENS. COMPETÊNCIA DO JUIZADO ESPECIAL CÍVEL. Sendo o pedido da autora certo, a devolução do cão da raça York Shire, não havendo discussão sobre a união afetiva que envolveria as partes, ou pretensão de partilha de bens, é de ser reconhecida a competência do Juizado Especial Cível. Sentença

83 BRASIL. Tribunal de Justiça De Santa Catarina. Disponível em:<http://portal. tjsc.jus.br/web/sala-de-imprensa/-/juiz-entende-que-cao-nao-e-objeto-e-remete-disputa-por-animal-para-vara-de-familia>. Acesso em: 19 out. 20165.

Juíz Leandro Katscharowski Aguiar. Titular da 7ạ Vara Cível da comarca de Joinville. Disponível em:<http://www.anda.jor.br/19/05/2016/juiz-entendeque-cao-nao-e-objeto-e-remete-disputa-por-animal-para-vara-de-familia-emjoinville-sc>. Acesso em: 19 out. 2016 
desconstituída. RECURSO PROVIDO. UNÂNIME. (Recurso Cível № 71004347357, Primeira Turma Recursal Cível, Turmas Recursais, Relator: Pedro Luiz Pozza, Julgado em 10/10/2013) ${ }^{85}$

Existe atualmente jurisprudência que confirma o conceito de que os animais não humanos têm a capacidade de sentir sensações, o STJ, em 2009, foi responsável por uniformizar o entendimento da Lei Federal: ${ }^{86}$

Não há como se entender que seres, como cães e gatos, que possuem um sistema nervoso desenvolvido e que por isso sentem dor, que demonstram ter afeto, ou seja, que possuem vida biológica e psicológica, possam ser considerados como coisas, como objetos materiais desprovidos de sinais vitais. Essa característica dos animais mais desenvolvidos é a principal causa da crescente conscientização da humanidade contra a p prática de atividades que possam ensejar maus tratos e crueldade contra tais seres.

RECURSO ESPECIAL № 1.115.916 - MG (2009/0005385-2) RELATOR: MINISTRO HUMBERTO MARTINS RECORRENTE: MUNICÍPIO DE BELO HORIZONTE PROCURADOR: ALEXANDRE ROSSI FIGUEIRA E OUTRO(S) RECORRIDO: MINISTÉRIO PÚBLICO DO ESTADO DE MINAS GERAIS RELATÓRIO O EXMO. SR. MINISTRO HUMBERTO MARTINS

É necessário que a fé ou religião, em conjunto com a ciência jurídica e a política se unam para que não seja criado dificuldades para que as comunidades reconheçam que nós humanos somos animais, que possuímos ligação direta com os animais não huma-

85 BRASIL. Tribunal de Justiça do Rio Grande do Sul. Recurso Cível: 71004347357 RS. Relator: Pedro Luiz Pozza. Porto Alegre, 10 de outubro de 2013.

${ }^{86}$ MÓL, Samylla, VENANCIO, Renato. A proteção jurídica aos animais no

Brasil: uma breve história. Rio de Janeiro: Editora FVG, 2014, p. 17. 
nos, tendo simetrias genéticas com determinados animais, ainda que este entendimento já é reconhecido na ciência, é necessário que também seja reconhecida na sociedade e no meio jurídico. ${ }^{87}$

\section{CONCLUSÃO}

Ser senciente é aquele capaz de sentir ou perceber através do sentido, é a sensibilidade e consciência de seres do reino animal. O sentimento e a dor vivenciado pelo animal não humano fazem com que se justifique a aplicação de direitos a eles. Inclusive, identifica-se que ao longo da evolução histórica grandes nomes da filosofia já tratavam os animais não humanos de forma diferenciada, como Pitágoras.

Cumpre destacar que na década de 70 fora levado para a UNESCO uma proposta de documento de caráter internacional que visava definir a conduta acerca da defesa dos animais não humanos, sendo que em 78, fora proclamada pela a UNESCO a Declaração dos Direitos dos Animais.

Ao longo da história da humanidade, contudo, pode-se verificar a existência de práticas de crueldade contra os animais não humanos, o que levou a criação de normas para regular e garantir defesa e preservação deles, além da Declaração dos Direitos dos Animais. Em consequência, observou-se a utilização da teoria dos direitos fundamentais que trouxe a proteção aos animais, vinculando à defesa do meio ambiente. Visualiza-se, porém, que houve a necessidade de mudanças mais concretas, com a observância e reconhecimento de que os animais não humanos devem ser seres de direitos.

Nesse raciocínio, aplicou-se o princípio da dignidade à vida aos animais não humanos, partindo do pressuposto que o mesmo é o mais indicado para fundamentar o tratamento de forma mais ética aos seres dotados de senciência. A doutrina já trazia esta

87 NOGUEIRA, Vânia Márcia Damasceno. Direitos fundamentais dos animais: a construção jurídica de uma titularidade para além dos seres humanos. 2012. 
referência, pois a dignidade à vida conduz valores e interesses naturais, racionalidade prática, a compaixão e o mais importante, a senciência.

Dessa forma, não mais considerando os animais não humanos como coisas ou objetos, mas sim seres que sentem sentimentos e sensações como nós humanos, o artigo 5ำ da Constituição Federal, juntamente com o artigo $1^{\mathfrak{0}}$ da Declaração dos Direitos dos Animais, de maneiras diferentes, remeteram ao tratamento igualitário entre os seres, ou seja, a igualdade de tratamento.

Cumpre esclarecer, todavia, que ao retratar-se de religião e animais, existem ainda controvérsias, uma vez que o Supremo Tribunal Federal aceita sacrifício de animais em religiões desde que sigam determinados ritos. Desse modo, conclui-se que esta luta está longe de terminar, porém há cada vez mais adeptos e que todos estão aos poucos se adequando a nova realidade, qual seja, que os animais possuem direitos e os humanos devem lutar por eles.

\section{REFERÊNCIAS}

AGÊNCIA DE NOTÍCIAS DE DIREITO DOS ANIMAIS. Senciência. Disponível em: <http://www.anda.jor.br/10/06/2009/senciencia>. Acesso em: 19 out. 2016

ANDA. Em decisão histórica França altera Código Civil e reconhece animais como seres sencientes. Disponível em: <https://www.google. com.br/url?sa=t\&rct=j\&q=\&esrc=s\&source=web\&cd=1\&cad=rja\&uact $=8 \&$ ved $=0$ ahUKEwjoq6081_TPAhVKGZAKHQWFBWgQFggcMAA\&url=h ttp\%3A\%2F\%2Fwww.anda.jor.br\%2F03\%2F02\%2F2015\%2Fdecisao-historica-franca-altera-codigo-civil-reconhece-animais-seres-sencientes\&usg=AFQjCNEIiJXE_zZoQNuDKvxiFVy-ErX4Tw>. Acesso em: 19 out. 2016.

ARRAES, Vania Marcia Damasceno Nogueira. Direitos fundamentais dos animais a construção jurídica de uma titularidade para além dos seres humanos. Editora, 2012.

BÍBLIA. A. T. Gênesis. In: BÍBLIA. Português. Bíblia sagrada: contendo o antigo e o novo testamento. Tradução de João Ferreira de Almeida. Rio de Janeiro: Sociedade Bíblica do Brasil, 1966. Gênesis, versículo 1: 20-25. 
BRASIL. Constituição (1988). Constituição Federal do Brasil de 1988. Disponível em: <http://www.planalto.gov.br/ccivil_03/Constituicao/ Constituicao.htm>. Acesso em: 22 out. 2016

BRASIL. Código Civil. Disponível em:<http://www.planalto.gov.br/ ccivil_03/leis/L9605.htm>. Acesso em: 19 out. 2016.

BRASIL. Decreto 24.645, de 10 de julho de 1934. Disponível em: <http://www.planalto.gov.br/ccivil_03/decreto/1930-1949/D24645. htm>. Acesso em: 19 out. 2016.

BRASIL. Decreto-Lei no 2.848, de 7 de dezembro de 1940. Disponível em:< http://www.planalto.gov.br/ccivil_03/decreto-lei/Del2848compilado.htm>. Acesso em: 19 out. 2016

BRASIL. Decreto Lei 3688, de 03 de outubro de 1941. Disponível em: < http://www.planalto.gov.br/ccivil_03/decreto-lei/Del3688.htm>. Acesso em: 19 out. 2016.

BRASIL. Lei 10.406, de 10 de janeiro de 2002. Disponível em:<http:// www.planalto.gov.br/ccivil_03/leis/2002/L10406compilada.htm>. Acesso em: 19 out. 2016.

BRASIL. Lei 9.605, de 12 de fevereiro de 1998. Disponível em: <http://www.planalto.gov.br/ccivil_03/leis/L9605.htm>. Acesso em: 19 out. 2016.

BRASIL. Tribunal de Justiça de Santa Catarina. Disponível em:<http:// portal.tjsc.jus.br/web/sala-de-imprensa/-/juiz-entende-que-cao-nao -e-objeto-e-remete-disputa-por-animal-para-vara-de-familia>. Acesso em: 19 out. 2016.

BRASIL. Tribunal de Justiça do Rio Grande do Sul. ADI: 70010129690 RS. Relator: Araken de Assis. Porto Alegre, 18 de abril de 2005.

BRASIL. Tribunal de Justiça do Rio Grande do Sul. Recurso Cível: 71004347357 RS. Relator: Pedro Luiz Pozza. Porto Alegre, 10 de outubro de 2013.

CAMPOS NETO, Antonio Augusto Machado de. 0 direito dos animais. Revista da Faculdade de Direito, Universidade de São Paulo.

CANOTILHO, José Joaquim Gomes; LEITE, José Rubens Morato (Org.). Direito Constitucional Ambiental Brasileiro. 3. ed. São Paulo: Editora Saraiva, 2010.

CHINA NA MINHA VIDA. Animais e as crenças chinesas. Disponível em:<https://chinanaminhavida.com/2011/06/19/animais-e-as-crencaschinesas/> Acesso em: 19 out. 2016 
CORREA, Bruna. Sacrifício de animais em rituais religiosos: o legado do retrocesso.

DIAS, Maria Berenice. Alimentos aos Bocados. São Paulo: Editora Revista dos Tribunais, 2013.

DOVAL, Lenize Maria Soares. Direitos dos Animais: uma abordagem histórico-filosófica e a percepção de bem-estar animal. Monografia. Graduação em Veterinária. Porto Alegre: Universidade Federal do Rio Grande do Sul. Faculdade de Veterinária. 2008. Disponível em: < http:// www.lume.ufrgs.br/bitstream/handle/10183/16438/000661804.pdf?sequence $=1>$. Acesso em: 19 out. 2016

DOVAL, Lenize Maria Soares. Direitos dos Animais: uma abordagem histórico-filosófica e a percepção de bem-estar animal. Porto Alegre, 2008.

FELIPE, S.T. Dos direitos morais aos direitos constitucionais: Para além do especismo elitista e eletivo. Salvador: Instituto de Abolicionismo Animal, 2007. Revista Brasileira de Direito Animal. v. 2, n.1, jun/2007

FIO CRUZ. Declaração Universal dos Direitos dos Animais. Disponível em: <http://www.fiocruz.br/biosseguranca/Bis/infantil/direitoanimais. htm>. Acesso em: 19 out. 2016

FRANCIONE, Gary L. Introdução aos direitos animais. Campinas: Editora Unicamp, 2013.

G1. Lei proíbe uso de animais em testes de cosméticos em Porto Alegre. Disponível em:<http://g1.globo.com/rs/rio-grande-do-sul/ noticia/2015/09/lei-proibe-uso-de-animais-em-testes-de-cosmeticos -em-porto-alegre.html>. Acesso em: 19 out. 2016

G1. Sob protestos, China realiza festival de carne de cachorro. Disponível em: < http://g1.globo.com/mundo/noticia/2016/06/sob-protestos-china-realiza-festival-de-carne-de-cachorro.html $>$. Acesso em: 19 out. 2016

GLAMORAMA. Bilionário brasileiro inaugura no Sul hospital público para animais. Disponível em: <http://glamurama.uol.com.br/ bilionario-brasileiro-inaugura-no-sul-hospital-publico-para-animais/> Acesso em: 19 out. 2016

HYPENESS. Holanda se torna o primeiro país sem cães abandonados - e não precisou sacrificar nenhum. Disponível em:http://www. hypeness.com.br/2016/07/holanda-se-torna-o-1o-pais-sem-caes-abandonados-e-sem-sacrificar-animal-algum/. Acesso em: 19 out. 2016 
IBDFAM. Magistrado considera cadela criatura senciente e declina competência sobre processo de posse para vara de família. Disponível em: <http://www.ibdfam.org.br/noticias/6004/Magistrado+considera+cadela+criatura+senciente+e+declina+compet\%C3\%AAncia+sobre+processo $+d e+$ posse + para + vara $+d e+f a m \% C 3 \% A D l i a>$. Acesso em: 19 out. 2016

IBOPE 2012. Disponível em: <https://vista-se.com.br/ibope-2012-152-milhoes-de-brasileiros-sao-vegetarianos/>. Acesso em: 19 out. 2016.

JUS BRASIL. RECURSO ESPECIAL n. 1.425.943 - RN do STJ. Disponível em:<http://www.jusbrasil.com.br/diarios/documentos/141119804/ recurso-especial-n-1425943-rn-do-stj>. Acesso em: 19 out. 2016

LEVAI, Laerte Fernando. Direito dos Animais. 0 direito deles e o nosso direito sobre eles. Campos do Jordão, São Paulo: Editora Mantiqueira, 1998.

LOPES, Bráulio. Direito com cultura. Disponível em: <https://direitocomcultura.wordpress.com/2010/08/13/art-225-vii-\%E2\%80\%93constituicao-federal-animais-tem-direitos-fundamentais-ou-sao-tutelados-pela-constituicao/>. Acesso em: 19 out. 2016

MEDEIROS, Fernanda Luiza Fontoura de. Direito dos Animais. Porto Alegre: Livraria do Advogado, 2013.

MEDEIROS, Fernanda Luiza Fontoura de. 0 Direito \& os Animais. 2. ed. Curitiba: Editora Juruá, 2012.

MINISTÉRIO PÚBLICO DO RIO GRANDE DO SUL. Ações Diretas e Incidentes de Inconstitucionalidade no TJ/RS. Disponível em:<https:// www.mprs.mp.br/adins/mostra_processo?numero=10824\&ano=2004> Acesso em: 19 out. 2016.

MÓL, Samylla, VENANCIO, Renato. A proteção jurídica aos animais no Brasil: uma breve história. Rio de Janeiro: Editora FVG, 2014.

MORAES, Alexandre de. Direito Constitucional. 24. ed. São Paulo: Editora Atlas S.A., 2009.

NOGUEIRA, Vânia Márcia Damasceno. Direitos fundamentais dos animais: a construção jurídica de uma titularidade para além dos seres humanos. 2012.

OLHAR ANIMAL. Nova Zelândia reconhece legalmente os animais como seres sencientes. Disponível em:<http://olharanimal.org/nova- 
zelandia-reconhece-legalmente-os-animais-como-seres-sencientes/> Acesso em: 19 out. 2016

OLIVEIRA, Gabriela Dias. Animais humanos e não humanos de Tom Regan. Ethic@, Florianópolis, v.3, n.3, p. 283-299, dez. 2004. Disponível em: <http://www.cfh.ufsc.b/rthic@/capa73.htm>. Acessado em: 19 out. 2016 OUTER ESPACE. Seria a mitologia Egípcia a melhor já criada na história da humanidade?. Disponível em:<http://forum.outerspace. com.br/index.php?threads/seria-a-mitologia-eg\%C3\%ADpcia-a-melhor-j\%C3\%A1-criada-na-hist\%C3\%B3ria-da-humanidade.447534/>. Acesso em: 19 out. 2016

PONTES, Bianca Calçada. SEDA: exemplo de políticas públicas para animais domésticos no município de Porto Alegre - Coleção CEJA. OAB/ RS, 2012. Editora Buqui.

PREFEITURA DE PORTO ALEGER. Sacrifício de animais em rituais religiosos: o legado do retrocesso. Disponível em:<http://www2. portoalegre.rs.gov.br/seda/default.php?reg=737\&p_secao=32>. Acesso em: 19 out. 2016

PREFEITURA DE PORTO ALEGRE. A SEDA. Disponível em:<http:// www2.portoalegre.rs.gov.br/seda/default.php?p_secao $=7>$. Acesso em: 19 out. 2016

PREFEITURA DE PORTO ALEGRE. São Leopoldo discutirá a criação de uma Secretaria Especial dos Direitos Animais. Disponível em: < http://www2.portoalegre.rs.gov.br/seda/default.php?reg=810\&p_secao $=32>$. Acesso em: 19 out. 2016

REVISTA VEJA. Disponível em: <http://veja.abril.com.br/multimidia/infograficos/a-historia-dos-direitos-dos-animais>. Acesso em: 19 out. 2016

RODRIGUES, Danielle Tetü. 0 Direito \& os Animais. 2. ed. Curitiba: Editora Juruá, 2012. p. 83- 84

ROUSSEAU, Jean Jacques. Discurso sobre a origem da desigualdade, 1754.Tradução Maria Lacerda de Moura. Edição Ridendo Castigat Mores. Edição eletrônica. Disponível em: <http//www. ebooksbrasil.org>. Acesso em: 19 out. 2016

SARMENTO, Daniel. Direitos fundamentais e relações privadas. 2. ed. Rio de Janeiro: Lumen Juris, 2006, p. 323. Disponível em: <http:// www.ambito-juridico.com.br/site/?n_link=revista_artigos_leitura\&artigo_id=11648>. Acesso em: 19 out. 2016 
SCIENCES ET AVENIR. Disponível em:<http://www.sciencesetavenir. fr/animaux/en-norvege-les-animaux-ont-leur-propre-police_100754> Acesso em: 19 out. 2016

SENADO FEDERAL. PROJETO DE LEI DA CÂMARA no 70, de 2014. Disponível em:<http://www25.senado.leg.br/web/atividade/materias/-/ materia/118217>. Acesso em: 19 out. 2016

SENADO FEDERAL. Utilização de animais na pesquisa e desenvolvimento de produtos cosméticos e de higiene pessoal. Disponível em: <https://www12.senado.leg.br/institucional/datasenado/enquetes/ internautas-apoiam-projeto-que-proibe-o-uso-de-animais-em-testesde-produtos-cosmeticos-e-de-higiene-pessoal>. Acesso em: 19 out. 2016 SENCIENTE. In: DICIONÁRIO AURÉLIO. Disponível em: <https://dicionariodoaurelio.com/senciente>. Acesso em: 19 out. 2016.

SENCIENTE. In: DICIONÁRIO ONLINE. Disponível em: <https://www. dicio.com.br/senciente/>. Acesso em: 19 out. 2016.

SENTIENS. In: GLOSSÁRIO. Disponível em: <http://www.sentiens.net/ top/PA_GLOSSARIO_top.html>. Acesso em: 19 out. 2016

SINGER, Peter. Libertação Animal - O Clássico Definitivo Sobre o Movimento Pelos Direitos dos Animais e exploração animal. Editora WMF Martins Fontes, 2010.

SUPREMO TRIBUNAL FEDERAL. Sacrifício de animais em rituais religiosos será discutido pelo STF. Disponível em:<http://www.stf. jus.br/portal/cms/verNoticiaDetalhe.asp?idConteudo=68292 $>$ Acesso em: 19 out. 2016.

TUDO SOBRE ANIMAL. Disponível em:<https://sofiaantunesmonteiro. wordpress.com/2013/04/16/a-historia-do-gato >. Acesso em: 19 out. 2016

VENANCIO, Renato. MÓL, Samylla. A proteção jurídica aos animais no Brasil - uma breve história. Editora FGV, 1. Ed. Rio de Janeiro, 2014.

VOLTAIRE. Dicionário Filosófico. Tradução Editora Matin Claret, 2004. Capítulo 8.

ZH NOTÍCIAS. Maltratar animais na Colômbia provocará prisão. Disponível em:<http://zh.clicrbs.com.br/rs/noticias/noticia/2016/01/ maltratar-animais-na-colombia-provocara-prisao-4946031.html >. Acesso em: 19 out. 2016 